Published in S Dow, J Jespersen and G Tily (eds), The General Theory and Keynes

for the $21^{\text {st }}$ Century. Cheltenham: Edward Elgar, 2018, pp. 132-44.

\title{
Keynes on Domestic and International Monetary Reform ${ }^{1}$
}

\begin{abstract}
Sheila Dow
Good theories are relevant abstractions, and relevance alters as history moves on (Chick 1983, p. 2)
\end{abstract}

\section{Introduction}

Within a capitalist economy, the institution of money both enables and constrains. It enables by providing a safe asset as the basis for contracts and as a refuge from uncertainty. But by the same token it constrains by providing an alternative to effective demand, creating unemployment, and by forming the basis for a financial system which can promote inequality of income and wealth. It was to address these concerns that Keynes put forward ideas for monetary reform, to create structures which would discourage the propensity to hoard money, 'a first approximation to the concept of liquidity preference' (Keynes [1936] 1973, p. 174) and to reduce the impact of such a propensity.

There has been considerable discussion of Keynes's ideas for monetary policy, but here the focus on monetary reform refers to the institutional arrangements within which monetary policy is conducted. Keynes was concerned, not only with monetary policy to address short-term fluctuations in liquidity preference, but also with the conditions of a monetary production economy. Therefore, in what follows we will draw attention to distinctions in Keynes's thinking on money. First, there is liquidity preference as a reasonable response to increases in uncertainty in the short run. Second, there is a secular heightening of liquidity preference as a reasonable response to a more long-standing state of economic vulnerability. But third there is a desire to hoard money for its own sake, which Keynes considered unreasonable. Finally there is the desire to amass financial wealth more generally, i.e., not necessarily held in liquid form, which is a primary characteristic of a monetary production economy.

In considering Keynes's thought on monetary reform in the changing contexts of his own lifetime and in relation to the modern era, we follow Victoria Chick's lead. She begins her account of The General Theory (Chick 1983) with Keynes's method. True to this method she proceeds to reconsider Keynes's theory in light of how history had moved on by the 1980s. In the companion volume to this one, Chick (20xx) updates the exercise by reconsidering Keynes's theory for the $21^{\text {st }}$ century. Here we follow in Chick's path by focusing on Keynes's views on monetary reform, domestic and international, in the light of developments since the 1930s and 1940s, and how they followed from an application of his general principles to that particular context. We then consider these ideas in the modern context. 


\section{Keynes on domestic and international monetary reform in his own time}

Keynes set out his priorities at the beginning of the final chapter of The General Theory as follows:

The outstanding faults of the economic society in which we live are its failure to provide for full employment and its arbitrary and inequitable distribution of wealth and incomes (Keynes [1936] 1973, p. 372).

Keynes had in earlier chapters addressed the problem of unemployment by means of the principle of effective demand, but proceeded to explain in the final chapter the interdependencies with distributional questions. While he was concerned that the economic system be efficient, Keynes understood efficiency in terms which included achieving the other two elements of his social philosophy: individual liberty and social justice (Keynes [1926] 1973, p. 311). This differs from the conventional understanding of efficiency in terms of constrained optimisation with respect to individual utility and profits, illustrating the importance of recognising the moral position embedded in theoretical structures. In terms of Keynes's social philosophy, unemployment was unacceptable: it was inefficient, wasting resources in a way which reduced both the liberty of the unemployed and social justice.

Keynes's policy solutions to unemployment extended beyond particular configurations of fiscal and monetary policy, addressing also the design of institutions to promote a supportive environment for enterprise. Since money played a crucial role in sustaining an underemployment equilibrium, he was particularly concerned with monetary institutions: their history and the scope for their reform. Central to Keynes's theory was his understanding of the nature of a monetary production economy, where the goal of production was financial accumulation rather than consumption (Rotheim 1981). The resulting rise in power of the financial sector over real economic activity conflicted with entrepreneurial priorities, as spelt out in chapter 12 of The General Theory: 'When the capital development of a country becomes a by-product of the activities of a casino, the job is likely to be ill-done' (Keynes [1936] 1973, p. 159). Of particular concern was not just accumulation of financial assets, but also the benefits to the rentier of liquid asset markets, which encouraged short-termism. Of greatest concern was the desire to accumulate the most liquid financial asset, money - the propensity to hoard.

Keynes's concern over hoarding/liquidity preference was a consistent thread in his thinking from his earliest studies of the monetary system, predating by two decades the culmination of his macroeconomics in The General Theory (Dostaler 2007). His first encounter with monetary systems was his study of Indian Currency and Finance (Keynes [1913] 1978, p. 100). The Indian economy with its gold-exchange standard was hampered by the commercial banks' need for gold reserves (given the absence of a central bank) and by the general propensity to hoard precious metals, which he regarded together as 'unfertile habits'. But what hoarding consisted of and what it implied for monetary reform depended on context. When considering the international monetary system in The Tract on Monetary Reform (Keynes [1923] 1971), he focused on the propensity of national governments, rather than banks or national populations, to hoard precious metals. This propensity underpinned his objections to the gold standard as an international 
monetary system because of the way in which it constrained domestic monetary systems and their ability to address monetary policy to domestic concerns. Keynes's thus focused on the problems of tying a domestic monetary system to an international asset of inelastic supply.

The idealised theoretical account of the gold standard assumed an automatic adjustment mechanism whereby countries in surplus would respond to gold inflows both by extending credit to deficit countries and by lowering interest rates in order to reverse inflows. The ebb and flow of gold, rather than its hoarding, was central to the adjustment mechanism. But in practice, with a general propensity to hoard from an inelastic supply of gold, countries seeking a surplus (and with the market power to do so) could induce inflows by tightening monetary conditions, with deflationary effects on the domestic economy and on deficit countries trying to stem capital outflows (Bibow 2009, pp. 160-1, Bibow 2017). Power exercised by those countries which could engineer a surplus in this way to address the demand to hoard would thus constrain economic possibilities for countries more prone to deficits and with less power in international capital markets, aggravating the maldistribution of adjustment to payments imbalance. Given the necessary symmetry of imbalances of payments, surplus countries could leave it to deficit countries to adjust. Unless deficit countries could induce sufficient capital inflows to offset trade deficits, they would be forced to adjust by means of deflation. Not only would this flout social justice with respect to distribution but it would also flout it by imposing a deflationary bias on the global economy. The gold standard was thus inefficient with respect to promoting full employment, individual liberty and social justice.

Whether the idealised account of the gold standard ever applied is a matter for debate (see e.g. Triffin 1964, pp. 2-20). But Keynes [1923] 1971) was convinced that it did not apply by the 1920s. By then, given the way the gold standard was working, it was reasonable for national governments to aim to hoard as a strategy in order to protect the domestic economy from the need to adjust to a balance of payments deficit. But, to the extent that patterns of payments imbalance persisted, and in particular to the extent that some countries would have ready access to international capital to address any deficit in any case, the propensity of countries in persistent surplus to hoard was unreasonable - it was a mechanism for exercising power in international finance. Whether reasonable or not, therefore, given that the propensity to hoard had a deflationary effect on the global economy, as well as promoting hardship in countries unable to satisfy their propensity to hoard, the solution lay in doing away with the gold standard system.

Keynes's early analysis of hoarding and its consequences thus focused on hoarding as a national priority, which had found expression in mercantilist policy emphasis on exports. But as his macroeconomics evolved with respect to the domestic economy, his focus shifted back to the propensity to hoard of private sector agents. His theory of liquidity preference portrayed the desire to hold liquid balances as a reasonable response to uncertainty, a factor that would vary in the short run. Although this was not the focus of The General Theory, in which he elaborated on the theory of liquidity preference as a short-run phenomenon, it could also be a reasonable response to a persistent state of uncertainty (particularly about effective demand and the availability of credit), as had been the case for lower-income countries in persistent deficit under the gold standard. 
But Keynes identified another basis for a long-standing propensity to hoard. Drawing on Marx, he saw the propensity to hoard as a characteristic feature of capitalist economies (Rotheim 1981). Drawing on Freud, Keynes depicted this propensity as unreasonable - a pathology (Dostaler 2007, Winslow 1995):

The love of money as a possession - as distinguished from the love of money as a means to the enjoyments and realities of life - will be recognised for what it is, a somewhat disgusting morbidity, one of those semi-criminal, semi-pathological propensities which one hands over with a shudder to the specialists in mental disease (Keynes [1930] 1973, p. 329).

Since raised liquidity preference as a result of uncertainty in the short or long terms reduced effective demand, Keynes was concerned to promote domestic macroeconomic stability, not only by means of countercyclical fiscal policy, but also through the judicious design and application of monetary policy addressed to maintaining a stable financial environment for economic activity (Tily 2007).

Considering monetary reform addressed to the secular propensity to hoard, Keynes ([1936] 1973: 353-8) was drawn to the proposals of Silvio Gesell which were directed precisely at the effect on aggregate demand. Ahead of the recent resurgence of interest in Gesell, Chick (2008) discussed Keynes's recognition that he had anticipated much of the analysis of The General Theory. Gesell had identified the monetary problem as arising from the fact that, unlike other goods or assets, money did not depreciate, encouraging hoarding. Indeed, since money originated in bank credit, the resulting payment of positive interest was a drain on the expenditure stream. If instead all money was centrally created, distributed through government expenditure and credit, and bore a cost (in his proposal, affixing a stamp at regular intervals to hoarded cash), then the incentive would be to keep money in circulation.

Keynes shared Gesell's concern about money hoarding being encouraged by its return (measured by the liquidity premium) and his analysis of interest as a monetary variable, and so was drawn to Gesell's proposed reform. While Keynes, unlike Gesell, was concerned with the specific problem of interest rates being held up during a slump by high liquidity preference as a short-run phenomenon, he was also concerned about the tendency of the fetish of monetary accumulation to hold interest rates too high for full employment in the long run; hence his appreciative discussion of usury laws (Keynes [1936] 1973, pp. 351-3). But Keynes argued that stamped money was not a practical solution. He disagreed that money could be defined by fiat, since the private sector was adept at developing alternative assets which had the required characteristics of money (a safe asset with low carrying costs and high liquidity). Further, even if it were feasible to define money by fiat, managing aggregate demand by means of centralised determination of the money supply would be confounded by discrete short-term shifts in liquidity preference. Instead, Keynes's economic programme would eventually drive the interest rate down to zero, ensuring the euthanasia of the rentier, by other means: a cheap money policy, the socialisation of investment, credit guidance and progressive taxation (Callegari 2017). 
Keynes's derivation of policy propositions from theoretical principles depended on the context to which they were to be applied. Having rejected Gesell's ideas for domestic monetary reform, he returned to a version of Gesell's ideas, and his own critique of the gold standard, when it came to plans for a new international monetary order after World War II. Indeed in chapter 23 of The General Theory Keynes's discussion of Gesell had followed directly on from a discussion of mercantilism. An efficient international monetary system would discourage the tendency of some countries to hoard gold, facilitated by expert-led growth, making it more difficult for countries with the corresponding trade deficits to adjust. Instead an efficient system would promote adjustment to structural (rather than temporary) payments imbalance in such a way as to spread the burden of adjustment equitably between surplus and deficit countries, with the rate of interest set at a rate to encourage investment, all with a reduced propensity to hoard. Keynes's ([1942] 1980) solution was to set up an International Clearing Union which would issue and manage an international money, bancor. Countries could avoid adjusting when imbalances were temporary by allowing their bancor balances to go into debit or credit. The availability of credit would obviate the need for individual countries to stockpile scarce international currency. But beyond a certain level, both debit and credit balances would face a charge designed to induce both deficit and surplus countries, respectively, to adjust in mutually-supportive fashion. The charge on surplus balances was equivalent to Gesell's stamped money, designed to discourage hoarding.

What was different about the context of the international monetary system in the 1940s compared to the domestic monetary system of the 1930s which could account for Keynes's application of Gesell's ideas to the former but not the latter? Keynes's main objection in the domestic context was that alternative forms of money would arise to satisfy the demand to hoard. But in the 1940s the problem being addressed was the absence of any international money. Domestic currencies were in general inconvertible and all international transactions were routed through central banks. It was feasible therefore to envisage a closed international monetary system in which the only players were national central banks. Indeed this is how the international monetary system could be characterised by the IMF up until the 1970s. Keynes was well aware that international capital markets could destabilise efforts to manage the international payments system and a focus on adjustment to structural payments imbalance by means of short-term capital flows. His Clearing Union would provide credit to obviate adjustment to temporary capital outflows and there would be controls on speculative flows (de Cecco 1979).

Like his proposal for charges on credit balances, this proposal did not survive the negotiations at Bretton Woods, for reasons which were primarily political. It was the US White Plan which prevailed, putting the US dollar, rather than gold or bancor, at the centre of the system as international money whose supply depended on US deficits. Bibow (2017) traces the consequences of this departure from the Keynes Plan, whereby the hegemony of the US has proved to be remarkably resilient. Geo-politics have been central to the way in which the international monetary system has functioned since 1944, and will continue to be central in the future. 


\section{Adaptation to the modern context}

In turning to consider Keynes's approach to domestic and international monetary reform in the modern context, we bear in mind Keynes's principle of effective demand, his characterisation of assets which perform money functions and the propensity to hoard, both as a secular tendency and as a short-run reaction to elevated levels of uncertainty. We also bear in mind Keynes's concern with social justice at a time of unacceptable degrees of inequality, domestic and international.

The 2008 banking crisis and its aftermath in stagnating economies and deteriorating social justice have encouraged renewed attention to monetary reform, at least at the domestic level, with echoes of debates on reform in the 1930s. There has been a revival of proposals for governments to wrest control of the money supply from banks. ${ }^{2}$ Interest in Gesell's work has experienced a revival, and negative interest rates have been applied in some banking systems, although they have not been applied, in Gesellian fashion, to retail deposits, or as a general solution regardless of economic conditions. ${ }^{3}$ Negative interest rates have been applied to bank reserves, following the failed attempts with quantitative easing to encourage banks to lend more to support real investment. But since credit creation is endogenous anyway, the critical factor has been weak investment demand, in the absence of fiscal support, combined with high risk assessment by banks of SME borrowers dependent on bank credit, which raises loan charges anyway. The outcome has been instead that, faced with squeezed margins on retail business, banks have sought profits elsewhere, fuelling the growth of shadow money and contributing to the continued overblown state of financial asset markets.

Indeed the greatest factor relative to Keynes's time has thus been the world-wide resumption of financialisation, a process which accelerated after the breakdown of Bretton Woods. While the Bretton Woods system, even without Keynes's key elements, had provided a stable basis for the growth in international finance, successive attempts at domestic monetary control (notably by the US) encouraged increasing recourse to asset markets outside national regulatory boundaries, within which inter-bank churning grew on a massive scale. By the same token, the success of Keynesian monetary policy addressed to promoting financial stability had encouraged financialisation at the domestic level and, ironically, inattention to questions of financial stability. A process of deregulation since the 1970s further encouraged this process and increased the integration of domestic financial markets with international markets. The result has been the escalating scale of financial activity and the increasing economic dominance of the rentier motivated by financial accumulation (see further Chick 20xx).

Where once it was possible to talk in terms of the world money supply as the managed stock of international assets held by central banks (e.g. in the context of estimating the desired addition to that stock with new issues of Special Drawing Rights), the volume of money assets held by the private sector has come to swamp the public sector. As in the domestic economy, so in the international economy the endogeneity of credit and money has taken on new force: the financial sector has increased its capacity to innovate in new forms of money as an alternative to 'official' money, as in the development of shadow money (Michell 2017, Caverzasi, Botta and Rochon 2016). Victoria Chick (1983, p. 358) wrote as follows: 'the elasticity of the postwar monetary 
system is probably the single most important area of departure from Keynes's assumptions ... [and] represents the area of the theory most in need of thorough revamping'. Her most recent emphasis (Chick 20xx) is on the way in which this ballooning of credit creation has focused increasingly on financial investment rather than real investment.

There continue to be persistent and large structural imbalances between national economies, reflecting an imbalance in power within the international economy (Bibow 2017). Even within structures like the euro-zone designed to promote economic convergence persistent large imbalances are evident from the TARGET2 payments settlement system which was expected to display balance between euro-zone member states as a result of economic convergence (Bibow 2015, Dow 2016). There is a euro-zone quantitative easing mechanism for providing liquidity which could alleviate these imbalances, either directly to banks or indirectly to governments. But again, without fiscal support, these efforts stumble at the obstacle of required collateral and its valuation, just as they do within other national circumstances.

At the global level, the IMF continues to provide credit to member countries facing temporary payments imbalances. In times of low risk perception, it has been commercial bank credit which has played the more significant role, as in the recycling of petrodollars in the 1970s. But the IMF's importance has re-emerged periodically during financial crises. Programmes have been introduced during periods of crisis for deficit countries where private sector finance was not made available. ${ }^{4}$ Then IMF conditionality became a prerequisite for private sector credit, until global liquidity recovered. But for some countries IMF credit has been conditional on structural adjustment programmes designed more as a long-term adjustment mechanism. These programmes have been highly controversial, being premised on a competitive global economic environment. But given the imbalance of power over terms of trade and access to private sector capital, the reliance on a conventional package of depreciating exchange rates, fiscal austerity, etc. has often been counter-productive for these countries and contributed to deflation of the global economy. As a result, the lowest-income countries, which are the most vulnerable to changing availability of credit and/or IMF conditionality, have for a long time sought to maintain positive balances in the international banking system (Dow 1995, Dow 1999). This is not just a reasonable preference for liquidity, but actual attainment of that liquidity has been at huge opportunity cost. The same pattern of a reasonable, yet deflationary, secular liquidity preference has been identified for vulnerable regions within national economies (see e.g. Dow 1992; see further Chick and Dow 1988).

With the increase in uncertainty following from the financial crisis, there has been an enhanced desire by all countries to hold assets in a secure form, particularly US dollar-denominated assets given the continuing strength of the dollar. But the crisis has yet again demonstrated the vulnerability of a system reliant on credit-creation in one country (the US), particularly when bank liabilities proved not to be safe. The preference is now for US Treasuries. But now even sovereign debt is not guaranteed to be secure given the scale of fiscal cost of the crisis. Since the 1970s there has been a secular increase in liquidity preference in the international monetary system, spawned by the instability which followed financial deregulation and the breakdown of the Bretton Woods system. Within that environment, higher liquidity preference was reasonable. 
But for countries with relatively secure balance of payments surpluses and access to international credit, hoarding of liquid international reserves verges on the pathological.

The system fails Keynes's requirements for efficiency, liberty and social justice. But where institutional arrangements are unsatisfactory, there is always scope for considering reform. The various modern proposals for controlling a stock of outside money, or inside money $100 \%$ backed by outside money, still fall under Keynes's critique of Gesell's stamped money. Yet Keynes's goal of inducing the euthanasia of the rentier and eliminating pathological hoarding could still be achieved by pursuing his reform programme of a cheap money policy, the socialisation of investment, credit guidance and progressive taxation.

Further, deregulation had exacerbated the scope for innovation to create ever-more credit through new types of asset and practices and the scope for increased liquidity preference to freeze markets. So reregulation should be able to curtail some of this scope again and act alongside a cheap money policy to foster a stable financial environment which would obviate the need for continued high levels of liquidity preference. An additional reform which would help to promote stability would be an international transactions tax designed to reduce the efficiency of a system which was promoting inefficiency. When likening the stock market to a casino, Keynes raised the possibility of applying to the stock market the conventional judgement 'that casinos should, in the public interest, be inaccessible and expensive' (Keynes [1936] 1973, p. 159). Further, the fiscal cost of the crisis arose from bail-outs extending beyond traditional banking. For some the solution is to eliminate bail-outs, and thus central bank support for banking in its entirety. But from a Keynesian perspective, society's need for a safe asset requires a retail banking system which has the full support of the central bank in exchange for acceptance of regulatory restrictions.

Given the way in which credit creation has been steered increasingly towards financial investment rather than real investment, it would be even more important than in Keynes's day that these restrictions include credit guidance measures. For the international monetary system, similarly, the principles of Keynes's reform plan still hold good. Davidson $(1982,1997)$ in particular has elaborated on what a modern version of the Keynes Plan could look like. He advocates a closed system of international payments operated by a world central banking system (the UMS) and denominated in International Money Clearing Units administered by the system. An overdraft facility would recycle credit balances to give short-term breathing room to countries with debit balances. But there would be a trigger point beyond which creditor countries would be obliged to spend down their balances, discouraging hoarding. The challenge, as for plans for control over money by domestic central banks, is the capacity for the private sector to create credit outside such a system, for governments as well as private sector borrowers.

\section{Conclusion}

Monetary reform in the pursuit of efficiency, liberty and social justice requires that the institutional structure be changed in order to affect the factors which promote a reasonable propensity to hoard and to penalise a pathological propensity to hoard. The challenges now are much greater than in Keynes's time because of the massive build-up of financialisation and the 
legacy of the exercise of power in the domestic and global economies. Yet the dangers of avoiding the issue are also greater as imbalances grow, between countries being forced into austerity regimes because of balance of payments deficits on the one hand and countries with persistent surpluses on the other, and as the international monetary system relies increasingly on capital inflows into the fragile financial system of the US. At the domestic level, as inequality grows and as the banking system preserves liquidity at the expense of households facing unemployment or wage stagnation, the trends are also deflationary. Yet the health of a financial sector exposed to over-inflated asset prices and to a state increasingly unwilling to support it relies crucially on the health of the real economy.

In both the domestic and international environments, the consequences of the propensity to hoard are critical. A monetary system which does not impose undue constraints on deficit units, but rather imposes an equal burden of adjustment on surplus units, would reduce the reasonable propensity to hoard on the part of deficit units. A stable financial environment, with stable provision of credit, with financial institutions constrained and directed by the state in exchange for lender-of-last-resort support, would reduce the reasonable propensity to hoard. In the international sphere this requires a money which is independent of any national economy.

What is critical is the propensity to hoard where there is no justification in economic vulnerability. This is a matter of personal and social psychology, but also of national policy. The only possible economic measure to address it is to penalise it financially, as in Keynes's economic programme leading to the euthanasia of the rentier and his scheme for an International Clearing Union.

\section{References}

Bibow, J. (2009), Keynes on Monetary policy, finance and uncertainty: liquidity preference theory and the global financial crisis, London: Routledge.

Bibow, J. (2015), 'The euro's savior? Assessing the ECB's crisis management performance and potential for crisis resolution', IMK Study 42, June.

Bibow, J. (2016), 'Symmetric global order with national self-determination and no hegemon: vision and reality', Skidmore College and Levy Economic Institute mimeo.

Callegari, B. (2017), 'The euthanasia of the rentier before and after Keynes', Norwegian Business School mimeo.

Caverzasi, E. and Botta, A. (2016), 'Shadow Banking and the Endogeneity of Money', Marche Polytechnic Universityand University of Greenwhich mimeo.

Chick, V. (1983), Macroeconomics After Keynes: a reconsideration of The General Theory, Cambridge, MA: MIT Press. 
Chick, V. (2008), 'Gesell, Silvio (1862-1930)' in S. N. Durlauf and L. E. Blume (eds), The New Palgrave Dictionary of Economics (second edition), London: Palgrave Macmillan. Available at http://www.dictionaryofeconomics.com.ezproxy.library.uvic.ca/article?id=pde2008_G000035, accessed 27 January 2016.

Chick, V. (20xx), 'Post-Keynesian perspectives for the $21^{\text {st }}$ century', in S. Dow, J. Jespersen and G. Tily (eds), Money, Method and Post-Keynesian Economics for the 21st Century, Cheltenham: Edward Elgar.

Chick, V. and Dow, S.C. (1988), 'A Post Keynesian Perspective on Banking and Regional Development', Thames Papers, Spring, pp. 1-22.

Davidson, P. (1982), International Money and the Real World, London: Macmillan.

Davidson, P. (1997), 'The General Theory in an open economy context', in G.C. Harcourt and P.A. Riach (eds), A 'Second Edition' of The General Theory, vol. 2, London: Routledge, pp. 10230.

De Cecco, M. (1979), 'The origins of the post-war payments system', Cambridge Journal of Economics, 3 (1), 49-61.

Dostaler, G. (2007), Keynes and His Battles, Cheltenham: Edward Elgar Publishing.

Dow, S.C. (1992), 'The Regional Financial Sector: A Scottish Case Study', Regional Studies, 26 (7), pp. 619-31.

Dow, S.C. (1995), 'Liquidity preference in international finance: the case of developing countries', in P. Wells (ed.), Post-Keynesian Economic Theory, London: Kluwer, pp. 1-16.

Dow, S.C. (1999), 'International Liquidity Preference and Endogenous Credit Creation', in J. Deprez and J. Harvey (eds), Foundations of International Economics, London: Routledge, pp. 15370.

Dow, S.C. (2016), 'Ontology and Theory for a Redesign of European Monetary Union', World Economic Review, 6, pp. 1-11.

Dyson, B., Hodgson, G. and Jackson, A. (2014), Creating a sovereign money system, London: Positive Money.

Keynes, J.M. ([1913] 1978), Indian Currency and Finance, Collected Writings, vol. I, London: Macmillan.

Keynes, J.M. ([1923] 1971), A Tract on Monetary Reform, Collected Writings, vol. IV, London: Macmillan.

Keynes, J.M. ([1926] 1973), 'Liberalism and Labour', in Essays in Persuasion, Collected Writings, vol. IX, London: Macmillan, 307-11. 
Keynes, J.M. ([1930] 1973), 'Economic Possibilities for our Grandchildren', in Essays in Persuasion, Collected Writings, vol. IX, London, Macmillan, pp. 321-32.

Keynes, J.M. ([1936] 1973), The General Theory of Employment, Interest and Money. Collected Writings, vol. VII, London: Macmillan.

Keynes, J.M. ([1942] 1980), 'Plan for an International Currency (or Clearing) Union', in Activities 1940-1944: Shaping the Post-War World: The Clearing Union, Collected Writing, vol. XXV, London: Macmillan, pp. 108-39.

Michell, J. (2017) 'Do Shadow Banks Create Money? "Financialisation" and the Monetary Circuit', Metroeconomica, 68 (2), 354-77.

Nersisyan, Y. (2012), 'Money Manager Capitalism', in J.E. King (ed.), The Elgar Companion to Post Keynesian Economics, second edition, Cheltenham: Edward Elgar Publishing, pp.409-13.

Rotheim, R. (1981), 'Keynes's monetary theory of value (1933)', Journal of Post Keynesian Economics, 3 (4), 568-85.

Tily, G. (2007), Keynes's General Theory, the Rate of Interest and 'Keynesian' Economics: Keynes Betrayed, London: Palgrave Macmillan.

Triffin. R. (1964), 'The evolution of the international monetary system', Princeton Studies in International Finance no. 12.

Ussher, L. (2012), 'International financial reform', in J.E. King (ed.), The Elgar Companion to Post Keynesian Economics, second edition, Cheltenham: Edward Elgar Publishing, pp.309-14.

Winslow, T. (1995), 'Uncertainty and liquidity preference', in S.C. Dow and J. Hillard (eds), Keynes, Knowledge and Uncertainty, Aldershot: Edward Elgar, pp. 221-43.

\footnotetext{
${ }^{1}$ This chapter has benefitted from comments from Victoria Chick, Jesper Jespersen and Geoff Tily.

${ }^{2}$ Although not discussed in these terms, a model would be the early decades of the post-war international monetary system, when international money was well-defined and under centralised control.

${ }^{3}$ Some detailed proposals, such as Dyson, Hodgson and Jackson (2014), would however involve depositors bearing the administrative costs of deposit management.

${ }^{4}$ Additional special programmes have been introduced to address particular needs, like buffer-stock financing.
} 